\title{
Trace elements in Gem-Quality Diamonds from De Beers' Victor Mine, Ontario, Canada
}

\author{
Mandy Y. Krebs, ${ }^{1}$ D. Graham Pearson, ${ }^{1}$ Thomas Stachel, ${ }^{1}$ Sarah Woodland, ${ }^{1}$ Ingrid \\ Chinn, ${ }^{2}$ and Julie Kong ${ }^{3}$ \\ ${ }^{1}$ University of Alberta,Edmonton,Canada, krebs@ualberta.ca, gdpearso@ualberta.ca, tstachel@ualberta.ca \\ ${ }^{2}$ De Beers Group Exploration, South Africa, Ingrid.Chinn@debeersgroup.com \\ ${ }^{3}$ De Beers Canada, Julie.Kong@debeersgroup.com
}

\section{Introduction}

In the same way that melt inclusions in phenocrysts have expanded our idea of melt formation and evolution in basalts, studying fluids trapped in diamonds is providing important new constraints on the nature of diamond-forming fluids. Fibrous and cloudy diamonds trap a high but variable density of so-called high-density fluid (HDF) inclusions and, therefore, have been extensively studied, with much progress being made recently in determining the nature of these HDFs using major and trace element compositions (e.g., Schrauder et al., 1996; Zedgenizov et al., 2007; Smith et al., 2012; Weiss et al., 2013, 2015; Klein-BenDavid et al., 2010; Klein-BenDavid et al., 2014 and references therein). In particular, two "endmember" mantle-normalised trace element patterns have been established (Fig. 1; Weiss et al., 2013); ribbed (highly fractionated inter-element ratios) and "planed" (less fractionated inter-element ratios). The "planed" patterns can clearly be related to asthenospherically derived melts whereas the "ribbed" patterns are proposed to represent increased interaction with the sub-continental lithospheric mantle. A key question is whether the same processes also drive the formation of gem diamonds. Constraining the nature of the diamond-forming fluid or melt for high purity gem-quality diamonds, however, is hampered by the sparsity of available high quality trace element data, mainly due to the extremely low concentrations of impurities that these diamonds contain. The recent discovery of fluids in gem diamonds showing similar major element chemistry to fluid-rich diamonds suggest that many diamonds may share a common spectrum of parental fluids (Jablon and Navon, 2016). Here we test this idea further using new trace element data from gem diamonds.

\section{Trace Elements in high purity gem diamonds fom the Victor Mine}

We present trace element data from gem-quality diamonds originating from De Beers' Victor Mine, Ontario, Canada whose paragenesis can be constrained from the solid macro-inclusions that they contain. Sixteen P-type diamonds - eight bearing silicate inclusions and eight with sulphide inclusions - were analyzed using a novel 'off-line' LA-ICP-MS sampling technique followed by sector-field ICPMS (McNeill et al., 2009). This method utilizes a closed-system laser ablation cell in which a diamond is ablated and the products trapped, allowing the accumulation of higher volumes of analyte, thus greatly increasing the chance of producing quantitative data by improving the "signal to noise ratio" many times over 'on-line' laser ablation. Solutions are analysed against matrix-matched standard solutions for calibration. The analysed area of each diamond was optically free of solid inclusions or other impurities at the 10 micron scale.

The concentrations of a wide range of elements for all analyzed high quality gem diamonds from the Victor diamond mine are very low, with medians for $\mathrm{Sr}(9 \mathrm{ppb}), \mathrm{Rb}(8 \mathrm{ppb}), \mathrm{Ba}(20 \mathrm{ppb}), \mathrm{U}(0.3 \mathrm{ppb})$ and $\mathrm{Y}(2 \mathrm{ppb})$, and REE abundances varying from 0.1 to $0.0001 \mathrm{x}$ chondrite. Consistent with their inclusion content (silicates or sulphides), the Victor diamonds can be devided into two compositional groups: Silicate inclusion-bearing diamond have more fractionated $\mathrm{REE}_{\mathrm{N}}$ patterns (median $\mathrm{Ce}_{\mathrm{N}} / \mathrm{Yb}_{\mathrm{N}} \sim$ 40) than sulphide inclusions-bearing diamonds (median $\mathrm{Ce}_{\mathrm{N}} / \mathrm{Yb}_{\mathrm{N}} \sim 8$ ). In addition, sulphide inclusionbearing diamonds have more widely varying and generally higher siderophile element concentrations (e.g., $\mathrm{Ni}, \mathrm{Fe}$ and $\mathrm{Co}$ ). A select few ratios (such as $\mathrm{Sm} / \mathrm{Hf}$ ) are significantly more fractionated in the silicate-bearing diamonds at Victor, although overall these differences are not striking and also not 
consistent across all key trace element ratios. It, therefore, seems likely that the silicate and sulphidebearing diamonds formed by gradations of the same processes.

\section{Comparison with other gem diamonds}

The very low trace element concentrations for the analysed Victor diamonds are significantly lower than values reported for fibrous stones but consistent with "closed-cell" ablation data previously reported for high quality gem diamonds from the Cullinan and Kimberley Pool mines in South Africa, and the Udachnaya Mine in Siberia (McNeill et al., 2009; Melton et al., 2012). Overall, the multielement patterns for high-purity gem diamonds analysed from these locations compare well with Victor diamonds (Fig. 1). Somewhat less pure "gem" diamonds from the Newlands and Finsch kimberlites (W Kaapvaal craton), also analysed by "closed-cell" ablation, show significantly higher and more fractionated trace element concentrations, correlating broadly with their lower clarity.

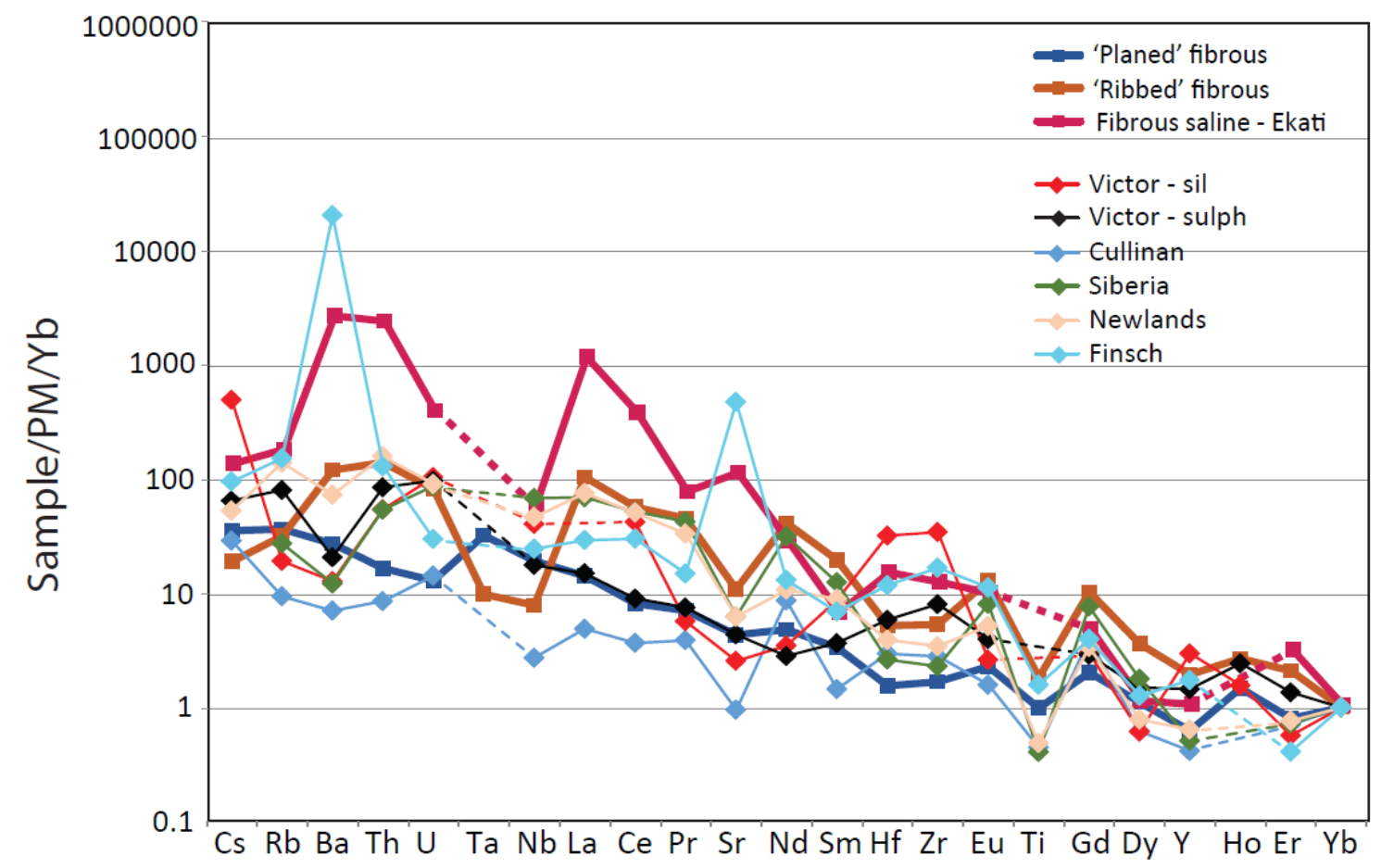

Figure 1: Double-normalised trace element patterns for gem quality diamonds from Victor (Canada; sulphide and silicate paragenesis), S. Africa (Cullinan, Newlands \& Finsch) and Siberia (Mir and Udachnaya) (this study and McNeill et al., 2009), for two common patterns, 'planed' and 'ribbed', of HDFs in fibrous diamond (Weiss et al., 2013) and for saline HDFs in fibrous diamond from the Fox kimberlite (Weiss et al., 2015). Samples are normalised to Primitive Upper Mantle and to a $\mathrm{Yb}$ value of $1 \mathrm{x}$ PUM to equalise variations in abundance levels caused largely by differences in fluid inclusion abundance.

Normalized first to primite mantle and then to a $\mathrm{Yb}_{\mathrm{N}}$ value of 1, the multi-element data reveal many similarities between the trace element characteristics of the gem diamonds (this study) and of fibrous, fluid-rich diamonds. Multi-element patterns for the high quality gem diamonds from Victor, Cullinan and Siberia resemble the less fractionated "planed" trace element pattern, while the Newlands diamond suite more closely resembles the 'ribbed' trace-element pattern, characterized by pronounced peaks and troughs. The Finsch diamonds, derived from a G10 garnet-bearing harzburgite, show striking positive anomalies in $\mathrm{Ba}$ and $\mathrm{Sr}$ that strongly resemble the patterns of fibrous diamonds containing "saline" inclusions (Fig. 1; e.g., Weiss et al., 2015). 


\section{Discussion}

Depending on the element, trace element abundances in Victor gem quality diamonds are among the lowest or the lowest measured in gem diamonds. This is conforming with the very high quality and value of the Victor production. Consistent with the major element determinations of Jablon and Navon (2016), we show clear similarities in the trace element patterns of fibrous and gem diamonds, indicating the presence of micro- to nanometer scale, highly dispersed fluid inclusions. While there are subtle differences between some sulphide and silicate-bearing diamonds at Victor, we view the fluids trapped within them as having broadly the same origin and having experienced similar petrogenetic processes, although varying in extent. The quantitative nature of the data produced in this study and that of McNeill et al. (2009) establishes clearly that "planed" trace element patterns characterise the parental fluids of both gem and fibrous diamonds. This fluid likely is a small-degree hydrous melt of carbonated peridotite and from our data, appears to invade both peridotitic and eclogitic diamond substrates. Our data also document the first direct link between some gem diamonds, sampled from a Finsch harzburgite, and highly saline fluids that have been proposed to originate from subducted slabs (Weiss et al., 2015). Overall, we see the same spectrum of fluids in gem diamonds that was previously documented in fibrous diamonds, consistent with similar compositions of diamond-forming fluids (at least in terms of major and trace elements) over billions of years (Smith et al., 2012).

\section{References}

Jablon BM, Navon O (2016) Most diamonds were created equal. Earth and Planetary Science Letters 443: 41-47.

Klein-BenDavid O, Pearson DG, Nowell GM, Ottley CJ, McNeill JCR, Cartigny P (2010) Mixed fluid sources involved in diamond growth constrained by constrained by $\mathrm{Sr}-\mathrm{Nd}-\mathrm{Pb}-\mathrm{C}-\mathrm{N}$ isotopes and trace elements. Earth and Planetary Science Letters 289: 123-133.

Klein BenDavid O, Pearson DG, Nowell GM, Ottley CJ, McNeill JCR, Logvinova A, Sobolev NV (2014) The sources and time-integrated evolution of diamond-forming fluids - trace elements and Sr isotopic evidence. Geochimica Cosmochimica Acta, Geochimica et Cosmochimica Acta 125: 146-169.

Melton GL, McNeill J, Stachel T, Pearson DG, Harris JW (2012) Trace elements in gem diamond from Akwatia, Ghana and DeBeers Pool, South Africa. Chemical Geology 314-317: 1-8.

McNeill JCR, Pearson DG, Klein-BenDavid O, Nowell GM, Ottley CJ, Chinn I (2009) Quantitative trace element analysis of gem quality diamonds. Journal of Physics: Condensed Matter 21: $364207,13 \mathrm{pp}$.

Schrauder M, Koeberl C, Navon O, (1996) Trace element analyses of fluidbearing diamonds from Jwaneng, Botswana: Geochimica et Cosmochimica Acta 60: 4711-4724.

Smith EM, Kopylova MG, Nowell GM, Pearson DG, Ryder J (2012) Archean mantle fluids preserved in fibrous diamonds from Wawa, Superior craton. Geology 40: 1071-1074.

Weiss Y, Griffin WL, Navon O (2013) Diamond-forming fluids in fibrous diamonds: The traceelement perspective. Earth and Planetary Science Letters 376: 110-125.

Weiss Y, McNeill J, Pearson DG, Nowell GM,Ottley CJ (2015) Highly saline fluids from a subducting slab as the source for fluid-rich diamonds. Nature 524: 339-342.

Zedgenizov DA, Rege S, Griffin WL, Kagi H, Shatsky VS (2007) Composition of trapped fluids in cuboid fibrous diamonds from the Udachnaya kimberlite: LAM-ICPMS analysis. Chemical Geology 240, 151-162. 